\title{
PENGEMBANGAN MODEL PEMBELAJARAN PROJECT CITIZEN \\ BERORIENTASI CIVIC KNOWLEDGE, CIVIC DISPOSITION, DAN CIVIC SKILL SEBAGAI INOVASI DALAM MATA KULIAH PENDIDIKAN PKn SD
}

Oleh :

\author{
Susilo Tri Widodo \\ Universitas Negeri Semarang \\ e-mail: susilotriwidodo@mail.unnes.ac.id \\ Renggani \\ Universitas Negeri Semarang \\ Sukarjo \\ Universitas Negeri Semarang
}

\begin{abstract}
ABSTRAK
Penelitian ini dilakukan dengan tujuan mengembangkan model pembelajaran project citizen yang berorientasi pada civic knowledge, civic disposition, dan civic skill sebagai bentuk inovasi dalam pembelajaran mata kuliah Pendidikan PKn SD. Inovasi model pembelajaran yang dikembangkan memberikan powerful learning atau belajar yang berbobot dan bermakna yang secara pedagogis bercirikan prinsip meaningful (bermakna), integrative (terpadu ), value based (berbasis nilai), chalengging (menantang), activiting (mengaktifkan) dan joyfull (menyenangkan) Penelitan ini dilaksanakan di jurusan Pendidikan Guru Sekolah Dasar, Fakultas Ilmu Pendidikan, Universitas Negeri Semarang. Subyek penelitian ini adalah mahasiswa. Penelitian ini merupakan penelitian pendidikan dengan pendekatan pengembangan $(R \& D)$.

Hasil penelitian pengembangan yang dilakukan menunjukkan rancangan model pembelajaran layak untuk dikembangkan dengan melihat uji kelayakan dari validator yang menunjukkan 94,62\%, penilaian produk tiap bagian dan keseluruhan yang menunjukkan rata-rata kategori sangat baik. Selain itu, dilihat dari terjadinya peningkatan kefeektifan penggunaan inovasi model pembelajaran yang dikembangkan. Peningkatan tersebut dari 50,43\% menjadi 89,22\% sehingga secara sederhana dapat dilihat terjadi signifikansi peningkatan 38,79\%. Berdasarkan hasil penelitian tersebut menunjukan bahwa inovasi model pembelajaran tersebut efektif untuk dikembangkan dalam pembelajaran mata kuliah PKn SD
\end{abstract}

Kata kunci : project citizen, pembelajaran, $P K n S D$ 


\section{PENDAHULUAN}

Pendidikan sebagai ujung tombak dalam rangka mencerdaskan kehidupan bangsa. Pembukaan Undang-Undang Dasar 1945 secara eksplisit memberikan penegasan bahwa tujuan nasional bangsa Indonesia salah satunya yaitu mencerdaskan kehidupan bangsa. Konsepsi yang telah digagas oleh para founding fathers tersebut menjadi dasar kuat bagi bangsa ini untuk selalu memperbaiki sistem pendidikan sesuai dengan kebutuhan dan perkembangan yang ada dimasyarakat. Selain itu, dalam Pasal 31 ayat 1 UUD 1945, disebutkan secara jelas bagi warga negara Indonesia tentang jaminan hak pendidikan bagi seluruh warga negara Indonesia, secara eksplisit tertulis sebagai berikut : " Setiap warga negara berhak mendapat pengajaran " menjadi bukti sekaligus kewajiban bagi negara atau pemerintah untuk memenuhi hak atas pendidikan bagi warganya". Dalam konteks pasal 31 ayat 1 , setiap warga negara mengandung pengertian sebagai keseluruhan masyarakat tanpa membedakan latar belakang sosial, budaya, serta ekonominya. Artinya semua warga negara Indonesia tak terkecuali, memiliki hak untuk menuntut kepada negara terhadap pemenuhan kebutuhan pendidikan.

Pendidikan yang dikembangkan tidak akan lepas dengan adanya pengembangan kurikulum yang menjadi jantungnya pendidikan. Kurikulum dikembang-kan berdasarkan kebutuhan dan tuntutan perkembangan dalam dunia pendidikan. Kurikulum Pendidikan Tinggi berkembang didasarkan pada Perpres No. 8 tahun 2012 tentang Kerangka Kualifikasi Nasional Indonesia (KKNI), Permendikbud No. 73 tahun 2013 tentang Penerapan Kerangka Kualifikasi Nasional Indonesia (KKNI) Bidang Pendidikan Tinggi, Permendikbud No. 49 tahun 2014 tentang Standar Nasional Pendidikan Tinggi (SNPT) diperbaharui Permenristekdikti No. 44 tahun 2015, dan Permendikbud No. 154 tahun 2014 (Rumpun Ilmu Pengetahuan dan Teknologi dan Gelar Lulusan Perguruan Tinggi). Berdasarkan hal itu, maka Universitas Negeri Semarang melakukan rekonstruksi kurikulum di tahun 2015 berdasarkan peraturan tersebut dan disesuaikan dengan karkateristik UNNES yang mengembangankan nilai-nilai konservasi.

Implementasi kurikulum UNNES 2015 tersebut tidak lepas dengan implementasi aktivitas akademik berupa pembelajaran atau perkuliahan yang dilaksanakan. Pembelajaran merupakan suatu hal penting di dalam dunia pendidikan. Kegiatan pembelajaran selalu berhubungan dengan konsep belajar. Menurut Gagne (1984) dalam Martinis Yamin (2008 : 122), menyebutkan "Belajar sebagai suatu 
proses dimana organisme berubah perilakunya diakibatkan pengalaman". Hal itu dapat dimaknai bahwa belajar itu merupakan bagian dari sebuah pembelajaran. Menurut Rigeluth (1983) dalam Eveline Siregar dan Hartini Nara (2014 : 43). Teori pembelajaran ada dua yaitu teori preskriptif dan deskriptif, teori preskriptif adalah goal oriented sedangkan teori deskriptif adalah goal free. Hal tersebut dimaksudkan bahwa teori pembelajaran preskriptif berorientasi mencapai tujuan, sedangkan teori pembelajaran deskriptif dimaksudkan untuk memberikan hasil. Kegiatan pembelajaran yang seharusnya adalah pembelajaran yang efektif dan efisien, agar segala tujuan yang diharapkan dapat tercapai sehingga memberikan hasil yang diharapkan. Implikasi dengan kurikulum UNNES 2015 tersebut maka akan berpengaruh terhadap beberapa komponen pengembangan proses pembelajaran antara lain pendekatan pembelajaran, strategi pembelajaran, metode pembelajaran maupun teknik pembelajarannya. Rangkaian dari pendekatan, strategi, metode, dan teknik tersebut menjadi suatu bentuk yang dimaknai sebagai model pembelajaran.

Pengembangan model pembelajaran menjadi salah hal penting untuk diperhatikan oleh para pendidik. Menurut Sri Anitah (2015: 45), menyebutkan bahwa model pembelajaran merupakan suatu kerangka berpikir yang dipakai sebagai panduan untuk melaksanakan kegiatan dalam rangka mencapai tujuan tertentu. Konsep tersebut sejalan dengan pendapat Dick\& Carey (2005 : 15) menunjukan bahwa dalam model pembelajaran terdapat pendekatan pembelajaran yaitu suatu cara pandang terhadap sesuatu, strategi pembelajaran yaitu perpaduan dari urutan kegiatan dan cara pengorganisasian materi pelajaran, peserta didik, peralatan, bahan serta waktu yang digunakan dalam proses pembelajaran untuk mencapai tujuan yang telah ditetapkan, dan metode pembelajaran yaitu cara yang digunakan untuk penyampaian pembelajaran. Untuk itu, peneliti sebagai seorang pendidik mencoba untuk mengembangkan pembelajaran yang lebih efektif. Desain pembelajaran yang efektif ini disesuaikan dengan kebutuhan yang akan dicapai dalam pembelajaran.

Mata kuliah Pendidikan PKn SD merupakan salah satu mata kuliah wajib yang harus ditempuh mahasiswa S1 PGSD. Pendidikan PKn SD sebagai salah mata kuliah rumpun PKn. Kajian yang telah dilakukan oleh peneliti, memberikan penguatan bahwa dalam pembelajaran Pendidikan PKn SD ini perlu diberikan inovasi dalam rangka meningkatkan kualitas dan keefektivan pembelajaran yang dilakukan. Model Pembelajaran Project Citizen merupakan salah satu 
bentuk model yang cocok untuk di kembangkan untuk rumpun PKn. Pembelajaran berbasis project citizen yang diterapkan di lndonesia, diadaptasikan dari project citizen-nya Amerika. Akar filosofi proyek ini berasal dari filosofi pendidikan Parker yang menyatakan bahwa pendidikan itu harus menjadi pusat tindakan dan bersifat alami. Project citizen dapat diartikan sebagai wujud benda fisik, sebagai suatu proses sosial pedagogis, maupun sebagai adjective. Pembelajaran project citizen ini mernbina pembelajaran yang multi M3SE (materi, media, metode, sumber dan evaluasi) karena didalamnya mencakup berbagai ragam jenis kegiatan, media dan sumber serta pola evaluasinya diperuntukan untuk suatu tema/bahasan yang sama atau sejenis.

Model pembelajaran project citizen sebagai salah satu alternatif dalam menguatkan civic knowledge, civic disposition, dan civic skill. Civic knowledge merupakan pengetahuan kewarganegaraan, civic disposition merupakan karakter kewarganegaraan, dan civic skill merupakan keterampilan kewarganegaraan. Ketiga hal tersebut merupakan satu kesatuan yang terintegrasi dalam membentuk kompetensi dalam belajar pendidikan kewarganegaraan. Untuk itu perlu kemampuan pendidik dalam mengembangkan model tersebut untuk diaplikasikan dalam pembelajaran sehingga mampu menjadi salah satu inovasi pembelajaran yang dikembangkan. Berdasarkan uraian diatas peneliti merancang sebuah penelitian dengan melakukan pengembangan model project citizen berorientasi civic knowledge, civic disposition, dan civic skill sebagai inovasi dalam mata kuliah Pendidikan PKn SD. Hal tersebut, sejalan dengan pengembangan UNNES di tahun 2017 sebagai tahun reputasi. Rancangan penelitian ini juga mendukung rencana strategis UNNES 2015-2019 untuk topik penelitian inovasi pembelajaran yang termasuk dalam bidang inovasi pendidikan berkualitas dan berkarakter.

\section{METODE PENELITIAN}

Penelitian ini merupakan penelitian pendidikan dengan pendekatan pengembangan (Research and Development/R\&D). Penelitian Research and Development merupakan metode penelitian yang digunakan untuk menghasilkan produk tertentu dan menguji kefektifan produk tersebut. (Sugiyono, 2015 : 407) 
1. Tahap-tahap dalam penelitian

Tahap dalam penelitian digambarkan dalam skema berikut :

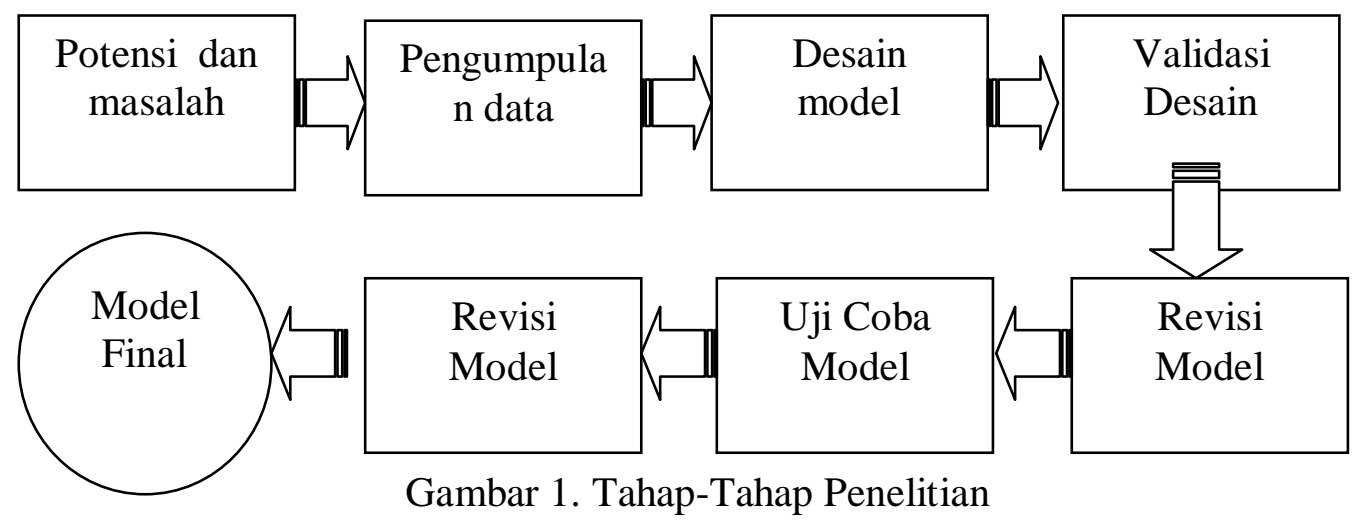

\section{Lokasi Penelitian}

Penelitian ini dilaksanakan di Semarang, khususnya pada jurusan Pendidikan Guru Sekolah Dasar, Fakultas Ilmu Pendidikan, Universitas Negeri Semarang. Lokasi ini dipilih karena penelitian ini diarahkan untuk meningkatkan kualitas pembelajaran dalam salah satu mata kuliah diprogram tersebut yaitu mata kuliah Pendidikan Kewarganegaraan Sekolah Dasar

3. Racangan Penelitian

Penelitian pengembangan dirancang melalui studi pendahuluan dengan pendekatan deskriptif kualitatif melalui pemetaan kebutuhan untuk meningkatkan kualitas pembelajaran dalam rangka akselerasi inovasi, kemudian dilanjutkan tahap pengembangan yang dimulai dengan perancangan inovasi model pembelajaran, validasi desain, serta perbaikan desain, dilanjutkan dengan uji coba model dengan menerapkan metode eksperimen, dilanjutan revisi model, dilanjutkan pengembangan model final.

4. Teknik pengumpulan data dan analisis data

Teknik pengumpulan data digunakan, pada saat studi pendahuluan menggunakan observasi dan studi dokumen, kedua teknik ini digunakan untuk melihat potensi dan masalah yang ada, kemudian pada saat studi pengembangan menggunakan desain model, kemudian pada saat uji coba terbatas menggunakan rancangan teknis model dan angket yang digunakan untuk mengetahui dan mengukur keberhasilan model. Sedangkan teknik analisis data yang digunakan yaitu analisis model berjenjang.Teknik analisis 
ini dilakukan untuk menghasilkan model final yang sesuai dengan target yang direncanakan

\section{HASIL PENELITIAN}

Penelitian yang dilaksanakan oleh tim peneliti melalui prosedur yang telah direncanakan mendapatkan berbagai hasil data di lapangan. Data tersebut akan di olah dan dianalisis sebagai hasil dari penelitian yang telah dilakukan.

\section{Analisis Data Studi Pendahuluan}

Tim peneliti telah melakukan studi pendahuluan dengan melihat capaian pembelajaran lulusan, capaian pembelajaran mata kuliah, dan kemampuan yang diharapkan dalam mata kuliah PKn SD sebagai berikut :

\section{a) Capaian Pembelajaran} Lulusan (CPL)

\section{Capaian Pembelajaran Sikap :}

- Menjadi insan manusia yang memiliki karakter sesuai nilai-nilai kewarganegaraan dalam kehidupan bermasyarakat, berbangsa dan bernegara.

- Menjadi insan manusia yang mampu mengembangkan nilai-nilai konservasi dalam kehidupan kampus maupun lingkungan masyarakat

- Menjadi insan manusia yang profesional, berkarakter mulia, dan berwawasan konservasi sehingga mampu bersaing di era globalisasi

\section{Capaian Pengetahuan :}

Pembelajaran

- Memiliki pengetahuan tentang pendidikan PKn SD dari sisi filosofis, historis, yuridis, dan sosiologis sebagai dasar dalam kehidupan bermasyarakat, berbangsa dan bernegara

- Memiliki pengetahuan tentang makna urgensi kajian pendidikan PKn SD sehingga mengikuti perkembangan keilmuan PKn

- Memiliki pengetahuan tentang aktualisas pendidikan PKn SD dalam kehidupan kampus maupun lingkungan masyarakat dalam mengahadapi era global

\section{Capaian}

Pembelajaran

\section{Keterampilan Umum :}

Memiliki kemampuan memahami perkembangan PKn dalam konteks filosofis, historis, yuridis, dan sosiologis sehingga mampu mengaktualisasikannya dalam kehidupan bermasyarakat, berbangsa dan bernegara dalam menghadapi tantangan global

\section{Capaian Pembelajaran}

\section{Keterampilan Khusus :}

Memiliki kemampuan dalam menghadapi segala tantangan yang bersifat dinamis dalam kehidupan kampus maupun lingkungan masyarakat, bangsa, 
dan negara melalui pengembangan keilmuan PKn

b) Capaian Pembelajaran Mata Kuliah (CPMK) :

Capaian Pembelajaran Sikap :

Memiliki sikap dan karakter yang sesuai dengan nilai-nilai kewarganegaraan dan nilai-nilai konservasi

\section{Capaian \\ Pembelajaran}

Pengetahuan :

Memiliki kompetensi profesional dalam menjelaskan perkembangan $\mathrm{PKn}$ dalam mendukung keilmuan PKn

Capaian

Pembelajaran

Keterampilan Umum:

Memiliki kemampuan memahami dan mengkatualiasasikan nilainilai kewarganegaraan dan nilainilai konservasi

Capaian

Pembelajaran

\section{Keterampilan Khusus :}

Mampu mengimplementasikan nilai-nilai kewarganegaraan dan nilai-nilai konservasi dalam menghadapi tantangan kehidupan yang bersifat dinamis

Setelah melihat CPL dan CPMK mata kuliah PKn SD maka model project citizen berdasarkan kajian secara teoritis dan praktis, menurut hemat peneliti dapat digunakan dan dikembangkan diperkuliahan sebagai bentuk inovasi model pembelajaran. Berdasarkan analisis lebih lanjut dengan melihat kemampuan yang diharapkan dalam mata kuliah ini maka peneliti memetakan dengan memilih materi yang cocok untuk pengembangan model project citizen.

Pembelajaran yang efektif merupakan hal penting yang harus dikembangkan oleh setiap pendidik dalam melaksanakan kegiatan belajar mengajar di kelas. Pembelajaran efektif setidaknya dapat mendorong tingkat keberhasilan pendidik dalam mencapai target dan tujuan pembelajaran. Untuk mewujudkan pembelajaran yang efektif maka pendidik harus mampu melakukan inovasi-inovasi sesuai dengan kebutuhan yang ada di lapangan. Inovasi tersebut dapat dilakukan dalam berbagai komponen pembelajaran seperti model, metode, media,strategi dan lain sebagainya.

Inovasi model pembelajaran merupakan salah satu upaya untuk menghasilkan pembelajaran yang efektif. Inovasi menurut John Clark dan Ken Guy (1997 : 2) berasal dari bahasa inggris innovation dapat diartikan sebagai proses dan/atau hasil pengembangan pemanfaatan/ mobilisasi pengetahuan, keterampilan (termasuk keterampilan teknologis) dan pengalaman untuk menciptakan atau memperbaiki produk (barang dan/atau jasa), proses, dan/atau sistem yang baru, yang memberikan nilai yang berarti atau secara signifikan. Hal ini menunjukkan bahwa inovasi dapat diartikan sebagai pembaharuan terhadap produk yang sudah ada atau 
menciptakan produk baru yang belum dikembangkan. Model pembelajaran menurut Mel Silberman (2002 :17) diartikan sebagai prosedur sistematis dalam mengorganisasikan pengalaman belajar untuk mencapai tujuan belajar. Model pembelajaran mencakup pendekatan, strategi, dan metode pembelajaran. Saat ini telah banyak dikembangkan berbagai macam model pembelajaran, dari yang sederhana sampai model yang agak kompleks dan rumit karena memerlukan banyak alat bantu dalam penerapannya.

Penelitian yang telah dilakukan oleh tim peneliti, memfokuskan pada sebuah inovasi model untuk Pembelajaran PKn SD. Mata kuliah PKn SD merupakan salah satu bidang dalam rumpun PKn yang memberikan pembelajaran kepada mahasiswa dengan leearning outcome atau capaian pembelajaran yang jelas. Berdasarkan hasil data penelitian, maka dapat kita gambarkan secara garis besar ada 3 cakupan dalam capaian pembelajaran mata kuliah PKn SD yaitu pegetahuan kewarganegaraan (civic knowledge), karkater kewarganegaraan (civic disposition), dan ketrampilan kewargangeraan (civic skill).

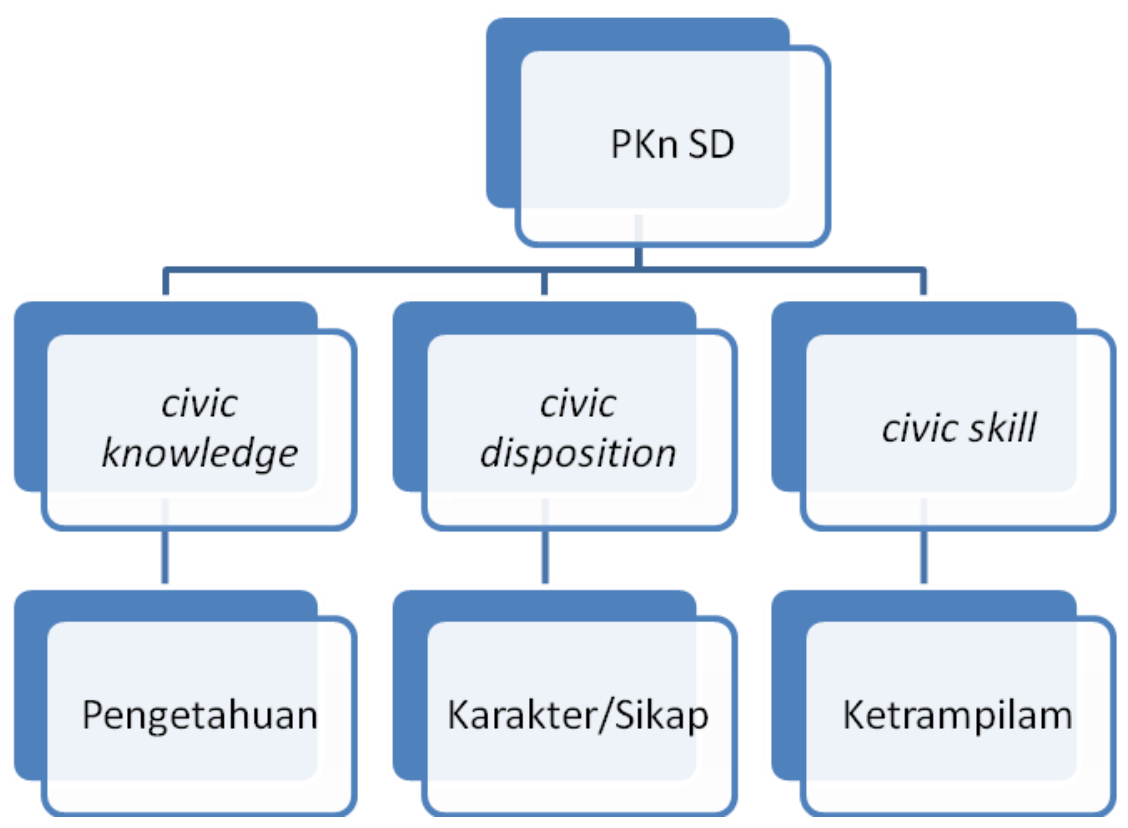

Gambar 2. Pemetaan Cakupan Capaian Pembelajaran MK PKn SD

Cakupan dalam capaian pembelajaran tersebut menjadi dasar dalam menentukan inovasi model pembelajaran yang akan dikembangkan oleh peneliti. Berbagai model pembelajaran yang sesuai dengan bidang PKn dapat dikembangkan sesuai 
dengan kebutuhan. Salah satu model yang inovatif dalam bidang PKn adalah model pembelajaran Project Citizen.

Project citizen dapat diartikan sebagai wujud benda fisik, sebagai suatu proses sosial pedagogis, maupun sebagai adjective. Sebagai wujud benda fisik, project citizen adalah sebuah kumpulan pekerjaan siswa yang bermanfaat, terintegrasi yang diseleksi dan disimpan dalam suatu bundle (Budimansyah, 2002:1). Dewey menawarkan berbagai metode dalam filosofi pendidikannya itu, yang terdiri dari lima fase yaitu: 1) cara berfikir yang "reflective thinking”; 2) proses hubungan social anak; 3) "guiding idea"; 4) "reasoning”; 5) ferivikasi gagasan dengan "experimental corroboration”.'Model

pembelajaran project citizen merupakan sebuah model pembelajaran yang lebih memberikan powerful learning atau belajar yang berbobot dan bermakna yang secara pedagogis bercirikan prinsip meaningful (bermakna), integrative (terpadu ), value based (berbasis nilai), chalengging (menantang), activiting (mengaktifkan) dan joyfull (menyenangkan).

Hasil penelitian menunjukkan bahwa model pembelajaran yang dikembangkan memberikan dampak positif terhadap proses pembelajaran yang dilaksanakan. Dampak tersebut juga dipengaruhi kesiapan peneliti dalam merancang inovasi model yang sebelumnya di validasi oleh ahli yang sesuai bidang peneltian. Hasil validasi dari validator ahli menunjukkan bahwa terdapat kelayakan terhadap inovasi model yang dikembangkan. Berikut analisis uji kelayakan model dalam bentuk grafik :

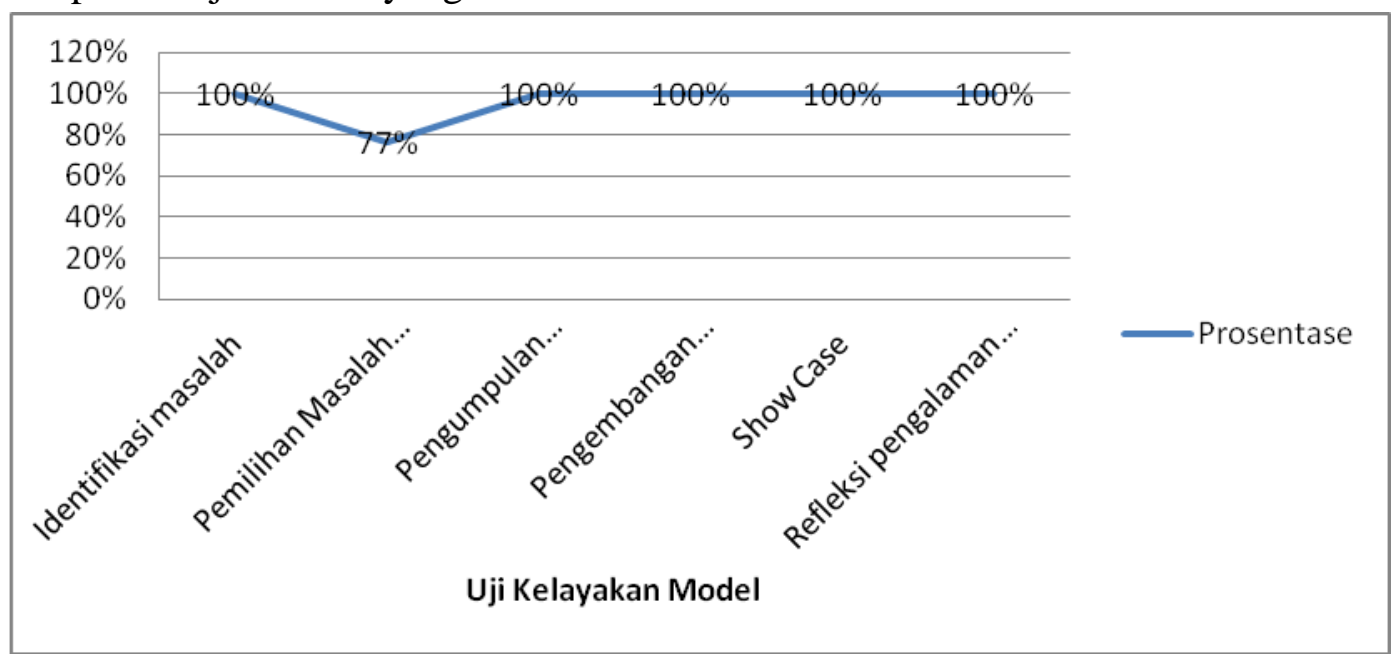

Gambar. 3 Grafik Uji Kelayakan Inovasi Model Project Citizen 
Sedangkan untuk melihat keberhasilan dan ketidakberhasilan dalam pengembangan model pembelajaran dapat dilihat dari : penilaian produk dan kefektifan model pembelajaran.
Penilaian produk yang dikembangkan yaitu pada tiap bagian dan keseluruhan portofolio. Penilaian produk pada tiap bagian dapat dilihat secara jelas melalui grafik berikut:

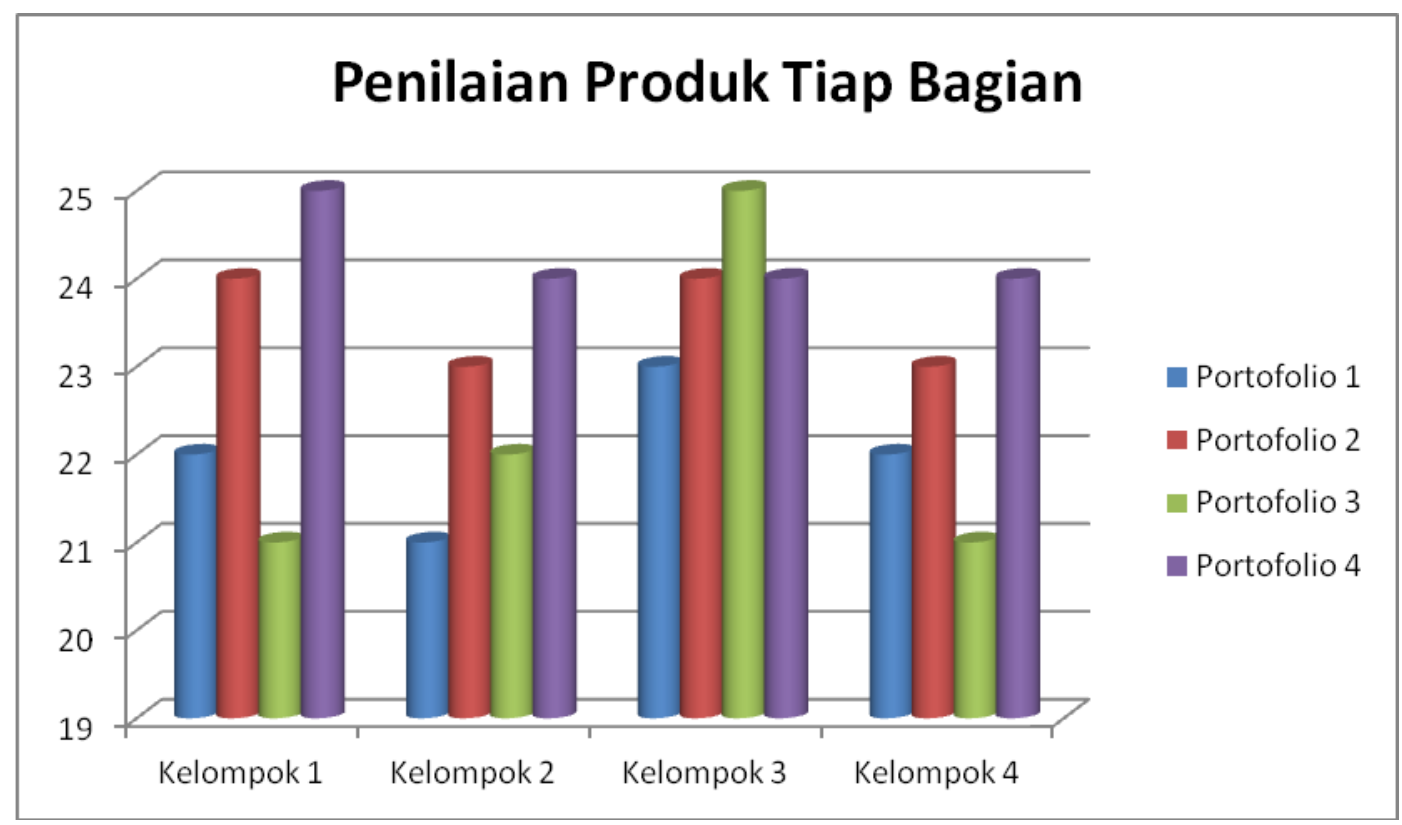

Gambar 4. Grafik Penilaian Produk pada Tiap Bagian Portofolio 
Sedangkan penilaian produk secara keseluruhan dapat

\begin{tabular}{|lr}
\hline & Portofolio Keseluruhan \\
Kelompok 1 & 14 \\
Kelompok 2 & 12 \\
Kelompok 3 & 13 \\
Kelompok 4 & 14 \\
\hline
\end{tabular}

dilihat dalam grafik sebagai berikut:

To resize chart data range, drag lower right corner of range.

Gambar 5. Grafik Penilaian Produk secara Keseluruhan Portofolio

Kedua grafik tersebut, menunjukkan penilaian hasil produk yang dikembangkan berdasarkan kriteria-kriteria dalam penilaian produk project citizen. Hal tersebut sejalan dengan pendapat Gagne (dalam Winatapura:1.19), menyatakan pembelajaran adalah serangkaian kegiatan yang dirancang untuk memungkinkan terjadinya proses belajar pada siswa. Instruction is a set of vents that affect learners insuch a way that learning is faciliated. Hal tersebut menunjukan bahwa produk yang dihasilkan dapat melalui proses yang memungkinkan terjadinya proses belajar pada diri setiap individu.

Sedangkan keberhasilan berikutnya dapat dilihat dari angket tanggapan mahasiswa terhadap kefektifan model pembelajaran project citizen yang dilihat dari implementasi pendekatan,strategi, metode, dan teknik pembelajaran. Adapun grafiknya sebagai berikut : 


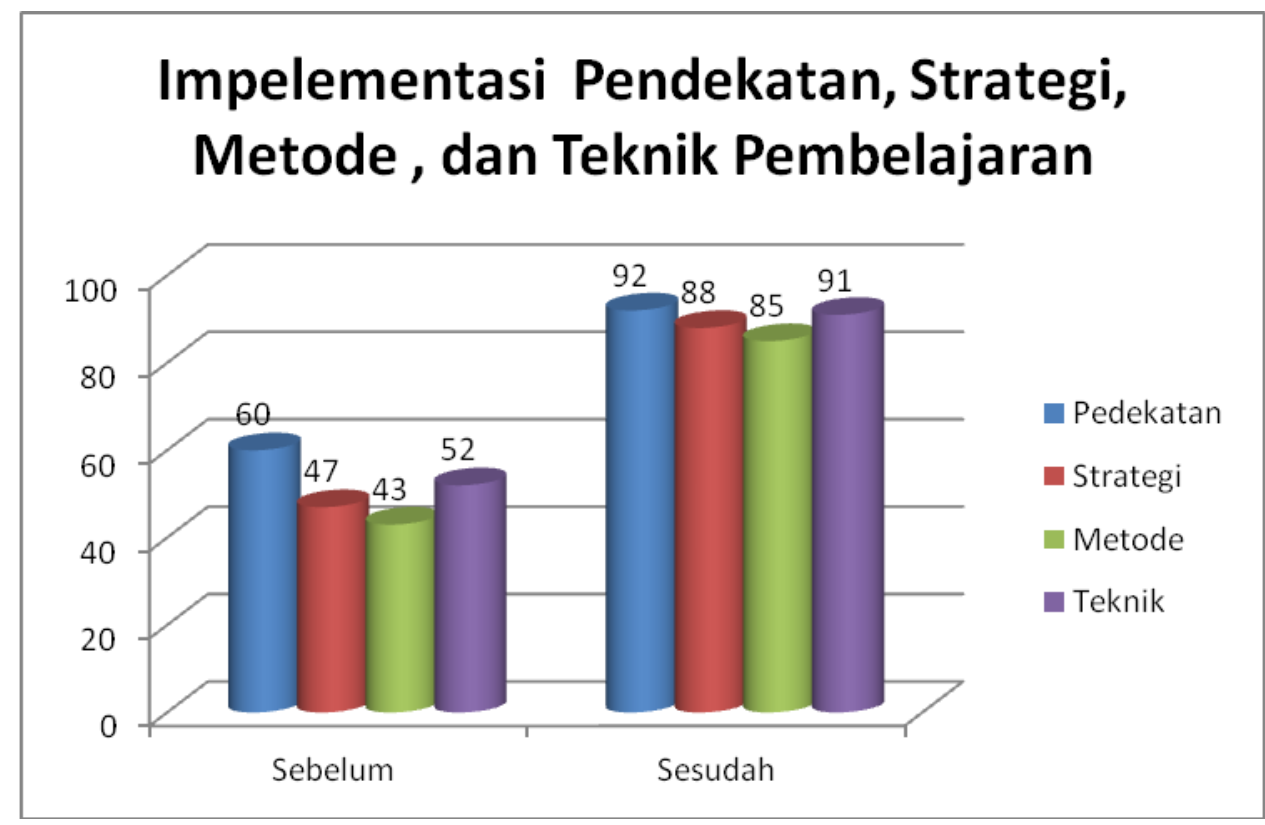

Gambar 6. Implementasi Pengembangan Pendekatan, Strategi, Metode, dan Teknik Pembelajaran

Berdasarkan grafik tersebut menunjukkan bahwa model pembelajaran project citizen menunjukkan kefektifan dengan peningkatan yang signifikan. Berdasarkan gambar tersebut menunjukkan prosentase tanggapan responden dari empat indikator inovasi model pembelajaran yang berupa pendekatan, strategi, metode, dan teknik yang diimplementasikan sebelum dan sesudah menggunakan model yang dikembangkan. Secara jelas, dari grafik tersebut terjadi menunjukkan progres dari tiap indikator sehingga sebagai salah satu bukti kefektifan inovasi model pembelajaran yang dikembangkan. Indikator tersebut sebagai parameter dalam mengukur kefekitifan model pembelajaran yang dikembangkan karena berdasarkan konsep sebelumnya yang menunjukkan bahwa sebuah model pembelajaran di dalamnya memuat pendekatan, strategi, metode, maupun teknik pembelajaran. Hal tersbut di dukung dengan hasil penelitian Susilo Tri Widodo,dkk (2016 :39) yang menunjukkan bahwa inovasi pengembangan model pembelajaran dapat mendorong terhadap keberhasilan pembelajaran yang dilakukan. Selain itu, penelitian ini dikuatkan oleh pendapat Sri Anitah (2014 : 45), yang menyatakan model adalah suatu kerangka berpikir yang dipakai sebagai panduan untuk melaksanakan kegiatan dalam rangka mencapai tujuan tertentu. Hal tersebut apabila dikaitkan dengan pembelajaran menunjukkan secara jelas bahwa model pembelajaran dapat diartikan sebagai kerangka 
berpikir dalam pembelajaran dalam rangka mencapai tujuan pembelajaran yang diharapkan. Melalui inovasi model pembelajaran dapat menuju pada pembelajaran yang efektif. Selain itu dikuatkan oleh pendapat yang menyatakan sebuah pembelajaran yang efektif yaitu guru memberikan kesempatan kepada siswa untuk berfikir agar mengenal dan memahami sesuatu yang sedang dipelajari (Darsono dalam Hamdani, 2011: 23).

\section{KESIMPULAN}

Pengembangan model pembelajaran project citizen menjadi salah satu bentuk inovasi model pembelajaran yang dikembangkan memberikan powerful learning atau belajar yang berbobot dan bermakna yang secara pedagogis bercirikan prinsip meaningful (bermakna), integrative (terpadu), value based (berbasis nilai), chalengging (menantang), activiting (mengaktifkan) dan joyfull (menyenangkan). Pengembangan yang dilakukan menunjukkan rancangan model pembelajaran layak untuk dikembangkan dengan melihat uji kelayakan dari validator yang menunjukkan 94,62\%, penilaian produk tiap bagian dan keseluruhan yang menunjukkan rata-rata kategori sangat baik. Selain itu, dilihat dari terjadinya peningkatan kefeektifan penggunaan inovasi model pembelajaran yang dikembangkan. Peningkatan tersebut dari 50,43\% menjadi $89,22 \%$ sehingga secara sederhana dapat dilihat terjadi signifikansi peningkatan 38,79\%.

\section{DAFTAR PUSTAKA}

A. Kosasih Djahiri.1979. "Pengajaran Studi Sosial/IPS, Dasar-dasar Pengertian Metodologi Model Belajar Mengajar Ilmu Pengetahuan Sosial". Bandung: LPPP-IPS IKIP Bandung

Clark, John dan Ken Guy. 1997. "Innovation and Competitiveness”. Technopolis. July 1997

Dasim Budimansyah. 2009. "Inovasi Pembelajaran Project Citizen”. Bandung: Program Studi PKn SPs UPI.

Dimyati dan Soedjono. 1996. "Strategi Pembelajaran”. Jakarta : Rajawali Press

Eveline Siregar dan Hartini Nara. 20014. "Teori Belajar dan Pembelajaran".

Pupuh Fathurrohman dan M. Sobri Sutikno. 2010. "Strategi Belajar Mengajar Melalui Penanaman Konsep Umum dan Konsep Islami”. Bandung: P.T Refika Aditama

Sapriya dan Udin Winataputra. 2003. "Pendidikan Kewarganegaraan: Model Pengembangan Materi dan Pembelajaran". Bandung: Laboratorium Pendidikan Kewarganegaraan (PKn) FPIPS -UPI. 
Sri Anitah. 2014. "Teknologi Pembelajaran”. Surakarta : Learning Resources Center FKIP UNS

Sri Anitah. 2015. "Strategi Pembelajaran di SD”. Jakarta : UT Press

Sudiarto. 2010. "Strategi Pembelajaran”. Jakarta : Dikti

Sugiyono. 2015. "Metode Penelitian Pendidikan Pendekatan Kuantitatif, Kualitatif, dan R\&D”. Bandung : Alfabetal

Suwarma Al Muchtar. 2000. "Pengembangan Kemampuan Berpikir dan Nilai dalam Pendidikan IPS". Bandung: Gelar Pustaka Mandiri Bandung.

Udin S, Winataputra. 2001. "Pendidikan Kewarganegaraan Sebagai Wahana Sistemik Pendidikan Demokrasi”, Disertasi. Bandung: Program Pasca Sarjana Universitas Pendidikan Indonesia

Udin Winataputra. 2008. “Pembelajaran PKn SD”. Jakarta: Universitas Terbuka

Wina Sanjaya. 2010. "Perencanaan dan Desain Sistem Pembelajaran”. Jakarta: Kencana Prenada Media Group

Winarno. 2006. "Pendidikan Kewarganegaraan di Perguruan Tinggi”. Jakarta : Bumi Aksara

Perpres No. 8 tahun 2012 tentang Kerangka Kualifikasi Nasional Indonesia (KKNI)

Permendikbud No. 73 tahun 2013 tentang Penerapan Kerangka Kualifikasi Nasional Indonesia (KKNI) Bidang Pendidikan Tinggi

Permendikbud No. 49 tahun 2014 tentang Standar Nasional Pendidikan Tinggi (SNPT) diperbaharui Permenristekdikti No. 44 tahun 2015

Permendikbud No. 154 tahun 2014 (Rumpun Ilmu Pengetahuan dan Teknologi dan Gelar Lulusan Perguruan Tinggi)

Renstra UNNES 2015-2019

Peraturan Rektor No. 5 tahun 2017 